\title{
MARIA THERESA'S URBARIAL PATENT: ROYAL CONSCIENCE AND ENLIGHTENED HABSBURG ECONOMIC POLICY
}

\author{
GYÖRGY KURUCZ \\ Károli Gáspár University of the Reformed Church in Hungary \\ kurucz.gyorgy@kre.hu
}

\begin{abstract}
This paper is intended to shed some light on several aspects of Queen Maria Theresa's urbarial regulation introduced in the Kingdom of Hungary after 1767. The author argues that her chief councillor's, Count Kaunitz's stance on the tax free status of the Estates of the Kingdom of Hungary largely influenced the Queen's attitude to the Hungarian nobility, but her motifs of being compelled to protect the peasantry against seigneurial excesses were truely based on her Christian consience as well. At the same time, he also argues that the process of elaborating on a system of peasant rights and obligations towards their landlords were quite revealing of the discontent mood of contemporary Hungarian society. Finally, the paper conludes that the various provisions of the urbarial regulation of 1767 worked out by the Queen's councillor on Hungarian affairs, Pál Festetics, had long lasting effects on the evolvement of Hungary's land ownership rights even after the abolition of feudalism in 1848 .
\end{abstract}

Keywords: Maria Theresa, Count Wenzel Anton Kaunitz, Pál Festetics, taxation, reform policy, peasant rights and obligations, modern landownership

'I do not want to be doomed for some noblemen and magnates.' This notorious line of Queen Maria Theresa's letter to Lord Chief Justice Miklós Pálffy has often been quoted by Hungarian historians as a proof of her true Christian motif and of her determination to protect Hungary's peasantry against seigneurial excesses induced by the increasing number of complaints and supplications submitted directly to the Queen. ${ }^{1}$ Nevertheless, it goes without saying that this is a rather complex issue whose aspects should not simply be limited to the realm of royal conscience. Policies pursued by the Queen and her government may have had other priorities as well, exerting long lasting effects on contemporary Hungarian society, most of all, on the most numerous layers of contemporary tax payers. Furthermore, the period of enlightened Habsburg monarchs, the reigns of Maria Theresa and Joseph II, saw substantial efforts aimed at enhancing the economic performance of the Habsburg Empire, so the introduction of a standardised system of obligations and services of the peasantry both in the Habsburg hereditary lands and in Hungary can certainly be deemed as an integral part of an economic programme. ${ }^{2}$ 
In this paper we would like to outline the legal and technical background of the planning and implementation of the urbarial regulation. Moreover, we will illustrate that the implementation of this complex system had a rather far reaching effect as far as the modern agrarian reform of 1848, or in other words, the abolition of feudalism is concerned. For this reason, we will argue that the long term consequences of this specific administrative measure has somewhat been underrated, despite the fact that it definitely influenced modern landownership, land use and administration well after the mid-nineteenth century. We would also like to present a minor case study which may potentially justify certain views underpinning the positive effects of the urbarial patent exerted well before and after its promulgation on the attitude and everyday life of contemporary peasant communities.

John Bigland, a Yorkshire schoolmaster and popular historian states in the third volume of his comprehensive series Geographical and Historical View of the World published in London in 1810 that 'The Urbarium of Maria Theresa may be considered as a curious monument in the history of society and far more interesting than the relation of a battle or a siege.' 3

Considering that Bigland's work was published during the long period of French wars, this sentence might have have sounded rather perplexing, or even provocative, in an age when reports or literary accounts of spirited leadership and inspired commandering should have by all means been more appealing to the English public than reading about the plight of the Hungarian peasantry. Not surprisingly, the author certainly felt that stories of tyrannical reign, conflicts and controversies might sell extremely well to his readership, so he chose to elaborate on the character of Joseph II and his arbitrary methods regarding his stance on his Hungarian subjects at a far greater length. Although Bigland had never been to Austria or Hungary before, he relied on a respected English authority on Hungarian affairs, that is, Robert Townson, who had visited Hungary some twenty odd years before. Yet, the period concerned was much more complex than simply reducing its presentation to highlighting the stages of conflicts between enlightened monarchs and the disgruntled Hungarian nobility. ${ }^{4}$ It speaks for itself that a contemporary analysis of rural affairs of the Kingdom of Hungary drawn up by Károly Pauly, Clerk of the Royal Hungarian Chancery, did not fail to refer to Townson's remarks on the issue of urbarial regulations. ${ }^{5}$

No doubt, Townson's observations have ever since been considered seminal concerning the presentation of social conditions, including the general atmosphere of late eighteenth century Hungary. Moreover, European and Hungarian 
historiography tends to agree that Maria Theresa and Joseph II were genuinely keen on improving the situation of the peasantry. Naturally, opinions are divided as to what extent their policies were truly motivated by human sympathies, Christian ethics, or by sheer fiscal considerations. Macartney, for example, concluded in the early sixties that the primary motif behind the Urbarium had simply been to secure for the Crown a larger proportion of the peasants' production by limiting that of the landlord. In addition, the Crown was now able to act as the protector of the peasants against the 'tyranny' of the nobles. ${ }^{6}$ At the same time, the manifestations of the Queen's conviction have often been quoted as saying that the 'cruelty of their landlords' drove those wretched people to rebel and resort to aggressive actions in the mid-1760s. ${ }^{7}$ However, we would be wrong to suppose that the Court of Vienna had by then been moved by complaints of Hungary's peasant communities. The actual number of relevant documents is quite low at this point, even though the supplication of a specific Transdanubian village, Vörösberény, or at least the brief excerpt compiled on the basis of the contents of the said record whose excerpt was subsequently forwarded to the Queen herself might have sounded rather convincing: 'de severo dominii sui dominatu querulantur', that is, 'complaints are being made concerning the severity of their landlord'. ${ }^{8}$ Nevertheless, it should, be noted that the increasing number of peasant grievances and seigneurial excesses were not exclusively typical of Hungarian large estates, or committed by the estate management of the Hungarian nobility, for some regions of the Hereditary Lands were also affected and almost brought to the verge of open revolt, especially in Austrian Silesia or in the large estates of Bohemia. ${ }^{9}$

As for the background to the idea of interfering in Hungarian affairs, Maria Theresa followed suit of her predecessors, most notably her father, Charles VI (III), who also implemented administrative reforms in the Kingdom of Hungary. Yet, we should bear in mind that Charles disapproved of the oppressive methods of his father, Leopold I, and never openly challenged Hungary's estate constitutional system. Furthermore, during the early period of his reign, he relied on schemes or proposals submitted by a select committee of the Hungarian assembly, or by Count Sándor Károlyi himself, the key figure of brokering reconciliation and cooperation between the dynasty and the estates. ${ }^{10}$ Putting things into perspective, however, one might say it was inevitable that the unsuccessful outcome of the Seven Years War, that is, the Queen's failure to reconquer Silesia should bring about or increase government efforts to curtail the independence of Hungary's estate constitutional system. On establishing the Council of State, Chancellor Wenzel Anton von Kaunitz put the whole programme to paper, highlighting that future government practices should seek to decrease the influence of the Hungarian nobility as well as dispensing with the formal confirmation of the Diet of Hungary, that is, the monarch should refrain from convening it. It was concurrently stressed that the overall conditions of the Hungarian peasant- 
ry should be improved and protected from seigneurial excesses, thereby enabling this crucially important layer of contemporary Hungarian society to continue to pay increasing taxes. ${ }^{11}$

Nevertheless, both the Queen and the Chancellor went ahead with the usual procedural or constitutional pattern, the Diet of Hungary was convened in 1764 and the royal proposals were duly put forward to the Estates of Hungary. This occured with a view to making them increase contributions through direct taxation levied on the taxable layers of contemporary society, so that the depleted coffers of the state should be replenished. This intention seemed rather justifiable, because Count Kaunitz implied that the Kingdom of Hungary was lagging behind as far as the proportionate amounts of contributions of the individual Hereditary Lands were concerned. Yet, it should be noted that Kaunitz's view was later challanged by Councillor Karl von Zinzendorf who took a broader view of revenues and expenditures, saying, as has been acknowledged in Hungarian historiography by Ferenc Eckhart and Éva H. Balázs, that the Kingdom of Hungary's contributions should not be limited to the amounts deriving from direct taxation. However, incomes generated by mining, or the provisioning and quartering of the standing army should by all means be taken into account, not to mention the fact that the Hereditary Lands had not been destroyed and depopulated as a result of a long lasting Turkish occupation. As for aggregate figures, incomes from the Hereditary Lands totalled 36.2 million forints, whereas Hungary accounted for almost 50 per cent of this amount with her 16.8 million forints. ${ }^{12}$

Naturally, as one would expect, in January 1764 the Queen had consulted the Lieutenancy Council (Statthalterei), an executive body of specialist departments subordinated to the Royal Hungarian Chancery, as to what items should be tabled amongst the royal proposals. The Lieutenancy Council replied that the reaction of the Estates would firstly focus on the grievances arising from the illegal practices of handling urbarial lawsuits by the monarch herself in relation to the appeal process. Originally, seigneurial court decisions were put forward to the county courts which then forwarded their deliberations to the Lieutenancy Council, however, the Lieutenancy Council had for some time been compelled to forward the cases concerned for approval or final decision to the Queen herself. According to customary law, this should be deemed as illegal, pointed out the Lieutenancy Council, because the sole competent court of appeal, the Royal Bench or Table was excluded from this process which ultimately contravened the procedural provisions of the law in effect. ${ }^{13}$

Nevertheless, Maria Theresa rightly believed that her authority should remain unchallenged in this respect, for several of the reflections submitted to her by the Council of State concluded that the existing contracts between landlords and their peasants were illegal anyway and the monarch was constitutionally entitled to overrule and eliminate unlawful decisions. In addition, the Queen was influenced 
by many a suggestion set forth in different elaborations implying that she would turn out to be a true protector of her subjects as well, thereby reaping the love and gratefulness of the masses of oppressed peasants: 'mille benedictiones eadem Sua Maiestas habebit', that is, 'Your Majesty shall have a thousand praises'. ${ }^{14}$ The complex package of pros and cons became the responsibility of Pál Festetics, the Councillor of the Royal Hungarian Chamber, who was much more cautious and suggested that the issue of urbarial regulations should be the very last one of the bills proposed by the Queen. He expected the magnates to oppose it most passionately. Maria Theresa subsequently acted in accordance with Pál Festetics's council and the royal proposals tabled at the session of 5 July 1764 gave prominence to the issues of raising the war tax or contributions, including the modernisation of the noble insurrection, as well as promoting trade. The Diet reacted in the usual manner, whereby the Estates declared in their address of 14 September 1764 that they were unable to raise Hungary's war tax or contributions. ${ }^{15}$ In order to finally eliminate this issue, the noble deputies thought it more expedient, despite being instructed by the counties not to do so, to vote an additional increase of 300000 forints, thereby raising Hungary's contributions to a staggering level of 3,9 million forints a year. ${ }^{16}$ One might say, at least in broad terms, the Estates acted in accordance with the normal rules of parliamentary practice based on the idea of making rational concessions as well as anticipating similar gestures from the other party in return. Consequently, from that moment on, legislation initiated by the monarch to alter the traditional bonds and status of the tax paying peasantry was deemed as an infringement of the law and the whole issue became a matter of principle for the Estates of Hungary.

\section{II}

In order to do away with the anticipated obfuscation and alleviate the differences between the Court and the Estates of Hungary, the Upper Chamber suggested that there was not one law in the Corpus Juris that provided for the exclusion of the monarch from initiating and proposing a bill concerning the issue of urbarial regulations. Consequently, the Queen should be entitled to act in the matter concerned. Nevertheless, no legislation was actually put forward and the intransigent attitude of the Estates of Hungary served as an excuse for the Queen to be disenchanted with her subjects. The royal rescript of 21 May 1765 questioned the determination of certain deputies to promote the overall interests and welfare of the state, so the Diet was duly dissolved and the Court seemed by no means legally restricted to continue with the required measures aimed at curtailing seigneurial excesses. This explains why Cornelius Neny, the Queen's secretary, had instructed Pál Festetics in his letter of 20 March 1765 to work out an universally 
applicable sytem of regulations for the Kingdom of Hungary. 'Her Majesty wishes you to prepare a secret memorial concerning the possible modes of working out and implementing urbarial regulations in Hungary [...]'. As for the aftermath of the Diet, Maria Theresa declared that she had been determined to improve the conditions of the peasantry and she could have dissolved the Diet as early as the previous September, but she wanted to improve cooperation with the estates. Nevertheless, considering the outcome of the Diet, she was compelled to resort to other means, whereby she could carry on with her policy in order to maintain her internal peace and reassure her conscience regarding this specific issue. ${ }^{17}$

Pál Festetics followed his father, Kristóf Festetics, a former councillor to the Lieutenancy Council, as a loyal subject of the Habsburg dynasty. He first read law at the Protestant university of Leipzig before completing his studies in Nagyszombat and becoming a clerk and councillor to the Court Chamber (Hofkammer) in Vienna, the central office of finances, so he was rightly deemed capable of working out the system required. Nevertheless, it should be noted that even the correspondence with his father reflected the dissatisfaction of the nobility and warned his son that it could have grave consequences unless the peasantry were dealt with appropriate firmness. ${ }^{18}$ This paper cannot deal with the elaborate task of working out the regulations on the whole process, but suffice to say that the Queen commented on several aspects, for example, the size of holdings, or even peasant rights of common pasturage. The different classes of the Festetics Papers held in the National Archives of Hungary contain autograph notes with the remarks and comments of the Queen, including the idea of carrying out preliminary surveys throughout the country. ${ }^{19}$ The commissioners carrying out the surveys used standard 'fassiones ad novem puncta', thereby hoping to gather reliable information to eliminate striking anomalies and establish the basis of the appropriate amounts of arable fields and meadows providing the livelihood of the individual heads of families according to their registered status. For this reason, the key elements of the regulation was to set the appropriate extent as well as the quality of the taxable unit holding, then the set standards of rights and obligations of the parties concerned, that is, of the stratified layers of peasant communities as well as of the landlords. ${ }^{20}$

To put the various consequences of the urbarial regulation in the Kingdom of Hungary into perspective we should look at its diverse reception by the peasantry as well as its long term effects. As for the landlords' excessive demands of services, we must firstly be aware of striking regional differences. For example, in the demesne of Edelény, Borsod County, at the time of the death of the landlord Baron Jean Francois L'Huillier in 1730, heads of families owning minium two draft animals, irrespective of the size of the actual farm unit, were obliged to pay 2 forints a year and perform one day of labour per week. Cotters payed 1 forint and performed the same amount of labour in addition to the set amount of pro- 
duce, tithe, etc. ${ }^{21}$ However, Count István Esterházy who married L'Huillier's granddaughter, Countess Ludmilla Forgách, forcefully concluded a new contract in 1763 as a result of which owners of a complete holding were supposed to pay 6 forints, and worst of all, labour service with draft animals was increased to two days a week. Cotters were supposed to perform 3 days a week per annum. ${ }^{22}$

Consequently, it is quite revealing that even the news of royal comissioners being sent to register the existing rights and services performed by the various layers of contemporary peasantry according to a standard survey sheet consisting of nine points brought some changes. This induced Eszterházy to conclude a new contract with Edelény which was to remain in force 'until the publication of the Urbarium proper', because the inhabitants of the market town simply refused to undertake any services to Esterházy. It should also be noted that whereas the sizes and quality of arable fields and meadows, etc. held by the individual farmers were not itemized or standardized in it, the amount and nature of services to be duly performed were clearly specified, whereby each male inhabitant of Edelény 'with no exception at all' was supposed to perform one day of labour with draft animals. Naturally, it was possible for everybody to commute this obligation to a set amount of days of manual labour or render these services to cash payment. ${ }^{23}$

As opposed to the case of Edelény, the inhabitants of Báránd, Bihar County, incorporated in the demesnes of the Bishopric of Várad, annually compiled a customized contract of their own. In 1759, for example, the whole community was supposed to pay 179 forints of rent, and 488 forints for commuting all kinds of labour services to cash payments. Tithes had always been given in kind, but no presents at all! ${ }^{24}$ Nevertheless, we would like to emphasize that information was gathered by Pál Festetics from all counties, but it is obvious that the standards of Zala County where Pál Festetics himself was the head of one of the chief landowning families did seem to reappear in the draft as well as in the final versions of the royal regulation. ${ }^{25}$ The internal unit holding was to cover an area of 1 Hungarian 'hold'. According to the modern metric system it equates to 5755 square metres, that is, an area sown with two 'pozsonyi mérö' (Pressburger Metzen - 62,53 1) of seeds, an additional set amount of holds according to the classification of the fertility of arable fields, but minimum 16 holds, including a fixed area of meadows of various quality used on the basis of pasturage, thereby making a standard unit holding (sessio). In addition, the bearers of such unit holdings had the right to collect wood for fuel or timber in the lord's forests. In return, serfs were to pay 1 forint per year, but in two installments, as well as having to perform labour with draft animals for one day a week. Cotters with houses were supposed to complete 18 days per annum, cotters with no houses 12 days a year. In addition, they had to deliver tithe from the produce, including presents, etc. ${ }^{26}$ All in all, regional differences are quite striking, and at this point we should note that it was Pál Festetics's brother, Lajos Festetics, who made a record in connection with the imple- 
mentation and publication of the authorized versions of the urbarial regulations individually set for the villages and market towns in Zala, Somogy and Baranya Counties. In it he stated that the inhabitants of several communities were quite dissatisfied with regulations noting 'the patents being publicized for the civilians [i.e. the serfs and cotters] throw them to the ground, tread on them saying it was the lords' making to do them harm' ${ }^{27}$ In any case, we would be wrong to assume that each community welcomed the regulation with the same positive sentiments as the taxpayers of Edelény.

As for the ultimate purpose of easing the burdens of the taxpayers in rural communities, noone can give exact figures as to what extent the easing burdens of the peasantry influenced the profit orientating activity of the individual peasant farmers. Nevertheless, we can assume a relative progress in this respect if we look at some figures following the period of the introduction of Maria Theresa's urbarial regulation. It certainly implies a steady rise in the incomes of peasant communities since the commutation of labour services was becoming quite common in the large desmesnes both in the West and the East of Hungary throughout the second half of the eighteenth century. ${ }^{28}$

\section{III}

Finally, we would like to reflect on some of the psychological phenomena recorded at the time of the introducation of the urbarial patent. As mentioned before, Count István Eszterházy was compelled to agree to the terms and stipulations of a contract painstakingly laying down the rights as well as the services of the community of Edelény prior to the actual promulgation of the urbarial regulations set for the community in $1771 .^{29}$ The reason for this preliminary compilation of terms and conditions was that the excessive procedures of the Lord of Edelény brought the community to the verge of an open revolt, what is more, the inhabitants declined to do any kind of labour services originally due to their landlord. Eszterházy clearly felt the need to ease the situation if he did not want to lose his crops. Moreover, he had by then been informed that the council of Edelény compiled a catalogue of his excesses and sent it to the royal commissioners operating in Borsod County. ${ }^{30}$ If we look at the lengthy document we might be shocked by the cases revealing how his demesne administration abused its position by fining peasant families under various pretexts and intimidating the whole community. Yet, what is really shocking is that Eszterházy himself did not refrain from flogging his serfs, or in an another case, he virtually ripped off the moustache of a man, thereby severely wounding his face. ${ }^{31}$ This explains why his stewards failed to maintain the required level of services on the part of the peasant community. It should also be noted that after 1771 investigation records invariably contain 
references to the 'charitable Queen's patent' even if it came to restoring order in the course of a simple pub fight. ${ }^{32}$

As for far reaching effects, we can conclude that the standardization of the extent of unit holdings remained in effect right up to 1848. It should also be noted that the so called cotters' allotment as provided by Emperor Franz Joseph's open decree of 1853 as well as Act No 53 of 1871 were entirely based on the above classification, including the extent of arable fields and meadows, of Maria Theresa's urbarial regulation enacted with slight alterations by the Diet of 1832 and $1836 .{ }^{33}$ Consequently, the deeds of the land registry offices compiled after 1853 also relied on the above standards as provided by the urbarial regulation, thereby influencing modern landownership and the performance of the national economy.

\section{Notes}

1 Marczali, Henrik, Mária Terézia. Magyar Történelmi Társulat, Budapest, 1891. (reprint: Maecenas, Budapest, 1987.) 299. Vörös, Károly, Az úrbérrendezés. in Ember, Győző - Heckenast, Gusztáv (eds.): Magyarország története. vols. 1-2. Akadémiai Kiadó, Budapest, 1989. vol. 2. 927.

2 For a comprehensive view of the period see the relevant chapters of H. Balázs, Éva, Hungary and the Habsburgs 1765-1800. An Experiment in Enlightened Absolutism. CEU Press, Budapest-Cambridge, 1997. See also Beales, Derek, Joseph II. und der Josephinismus, in Reinalter, Helmut - Klueting, Harm (Hrsg.): Der aufgeklärte Absolutismus im europäischen Vergleich. Böhlau, Wien, 2002, 35-54. For the constitutional overview of the period concerned see Szijártó M. István, A Diéta. A magyar rendek és az országgyülés 1708-1792. Osiris, 2005.

3 Bigland, John, Geographical and Historical View of the World. vols. 1-5, Longman, Hurst, Rees, and Orme, London, 1810, vol. 3. 336.

4 Townson, Robert, Travels in Hungary, with a Short Account of Vienna in the Year 1793. Robinson, London, 1797.

5 Pauly, Károly, Constitutio rei urbarialis Regni Hungariae, vol. 1-2, Grundianis, Viennae, 1817. vol. 1. IV.

6 Macartney, C. A., Hungary. From Ninth Century Origins to the 1956 Uprising. Aldine Transaction, New Brunswick - London, 2009. 115-116.; Cf. Weckowicz-Liebel, Helen - Szabo, Franz J., Modernization Forces in Maria Theresa's Peasant Policies, 1740-1780. Histoire sociale Social History 15 (1982) No. 30 301-331., especially 303-305.

7 Kropf, Rudolf, Der Bauernaufstand von 1765/66 in der Herrschaft Schlaining. Burgenländische Heimatblätter 31 (1969) 121-143., especially 140-142. See also Kondicsné Kovács, Éva, Földesúr contra nádor. Parasztmozgalom a körmendi uradalomban. in: Móricz, Péter: Batthyány Lajos nádor. Körmendi Kulturális Központ, Múzeum és Könyvtár, Körmend, 2017. 85-98., especially 91-96.

8 Szabó, Dezső, A magyarországi úrbérrendezés története Mária Terézia korában. Magyar Történelmi Társulat, Budapest, 1933. 50.

9 Weckowicz-Liebel - Szabo, Modernization Forces, 314-315. 
10 Forgó, András (ed.), Az 1712. évi pozsonyi diéta egy ciszterci szerzetes szemével. Pannonhalmi Főapátsági Levéltár - Magyar Nemzeti Levéltár Veszprém Megyei Levéltára, 2013. 164-165. Szíjártó, M. István, A 18. századi Magyarország rendi országgyülése. Országház Könyvkiadó, Budapest, 2016. 107-120.

11 Ember, Győző, Magyarország és az Államtanács első tagjai. Századok 69 (1935/Beiheft) 555564., especially 663-664. See also further elaboration on it in H. Balázs, Hungary and the Habsburgs, 58-64.

12 Eckhart, Ferenc, A bécsi udvar gazdasági politikája Magyarországon Mária Terézia korában. Budavári Tudományos Társaság, Budapest, 1922. 348-349., H. Balázs, Éva, Hungary and the Habsburgs, 65-67. For basic figures concerning the rising debts on account of financing the military see Österreichische Staatsarchiv Kart. 5 AKA 5-5.

13 Szabó, A magyarországi úrbérrendezés, 7., Eckhart, Ferenc, Magyar alkotmány és jogtörténet. Osiris, Budapest, 2000. 260-263., Rady, Martyn, Customary Law in Hungary. Courts, Texts, and the Tripartitum, Oxford University Press, Oxford, 2015. 192-195.

14 Szabó, A magyarországi úrbérrendezés, 228.

15 Magyar Nemzeti Levéltár Országos Levéltára [Hungarian National Archives, MNL OL] Festetics Levéltár P 245 24. d.

16 Szijártó M., A Diéta, 595.

17 Ember, Győző, Mária Terézia úrbérrendezése és az államtanács, A Gróf Klebelsberg Kúnó Magyar Történetkutató Intézet Évkönyve 5. (1935) 140., Szabó, A magyarországi úrbérrendezés, 46-47.

18 MNL OL Festetics Levéltár P 245 24. d., Szabó, Dezső: A herceg Festetics család története. Franklin, Budapest, 1928, 69-89., Kurucz György, Keszthely grófja. Festetics György. Corvina, Budapest, 2013. 74-75.

19 MNL OL Festetics Levéltár P 245 3. d. III.

20 Pauly, Károly, Constitutio, vol. 1, 407-408. For a comprehensive view of the stratification of peasant communities in the Kingdom of Hungary see Varga, János, Jobbágyrendszer a magyarországi feudalizmus kései századaiban 1556-1767. Akadémiai, Budapest, 1969. 367-407. For the various aspects of land use, services and obligations in a given county see Wellmann, Imre, A parasztnép sorsa Pest megyében kétszáz évvel ezelött tualjdon vallomásai tükrében, Magyar Mezőgazdasági Múzeum, Budapest, 1967.

21 MNL OL Dessewffy Levéltár P 86 49. d. Fasc. B. f. 34

22 MNL OL Dessewffy Levéltár P 86 49. d. Fasc. B. f. 36

23 MNL OL Dessweffy Levéltár P 86 51. d. ff. 47-48

24 Balassa, Iván, Adatok Báránd XVIII. századi történetéhez, in Héthy, Zoltán (ed.), A Bihari Múzeum Évkönyve III. Bihari Múzeum, Berettyóújfalu, 1982. 155-165., especially 157-158.

25 Horváth, Zita, A Zala megyei parasztság helyzete a 18. században az úrbérrendezés forrásainak tükrében, Korall (2005) No. 19-20, 132-159., especially 146-147., 152-153.

26 Szabó, A magyarországi úrbérrendezés, 67-68.

27 MNL OL Festetics Levéltár P 235 107. d. No. 74. f. 483

28 MNL OL Károlyi Levéltár P 397 60. k., MNL OL Festetics Levéltár P 279 24. d.

29 MNL OL Dessewffy Levéltár P 89 2. d. No. 4 f. 24

30 MNL OL Dessewffy Levéltár P 86 51. d.. ff. 49-51v

31 MNL OL Dessewffy Levéltár P 86 52. d. Fasc. C. ff. 44-46v

32 MNL OL Dessewffy Levéltár P 86 52. d. Fasc. C. f. 147

33 Szabad, György, A zsellérilletmény, Agrártörténeti Szemle (1987) No. 1-2, 1-17. 